\title{
Efficacy of Fungicides Against Grain Discoloration Disease of Rice
}

\author{
V. A. Patil ${ }^{1}$, P. B. Patel ${ }^{1}$, P. D. Ghoghari ${ }^{1}$, N. K. Kavad ${ }^{1}$ and V. P. Usadadia ${ }^{2}$ \\ ${ }^{1}$ Rice Research Centre, SWMRU, Navsari Agricultural University, Navsari (396 450), India \\ ${ }^{2}$ Soil Water Management Research Unit, Navsari Agricultural University, Navsari (396 450), India
}

\section{Corresponding Author \\ V. A. Patil \\ e-mail:vapatil_swm@nau.in}

\author{
Article History \\ Article ID: IJEP0367 \\ Received in $18^{\text {th }}$ March, 2020 \\ Received in revised form $02^{\text {nd }}$ April, 2020 \\ Accepted in final form $10^{\text {th }}$ April, 2020
}

\begin{abstract}
Rice (Oryza sativa L.) is one of the important cereal crop grown extensively in Gujarat. It suffers from grain discoloration fungal disease causing heavy losses at maturity stage of rice. A field experiment was laid out with the single and new combinations fungicides against rice grain discoloration disease under field conditions during kharif-2013-14, 2014-15 and 2015-16. Six fungicides at various concentrations were screened against rice grain discoloration disease. The trifloxystrobin $25 \%+$ tebuconazole $50 \%$ (0.03 \%) @ $0.4 \mathrm{~g} \mathrm{l}^{-1}$ and propiconazole 25 EC (0.025\%) @ $1.0 \mathrm{ml} \mathrm{l}^{-1}$ was found effective against rice grain discoloration and recorded significantly higher healthy grains.
\end{abstract}

Keywords: Fungicides, grain discoloration, Oryza sativa

\section{Introduction}

Rice (Oryza sativa L.) is the staple food crop for people of south, south-east and eastern Asia where $90 \%$ of the world's rice is produced and consumed. It is grown in 114 countries across the world on an area of about 160 million hectares with

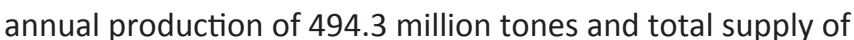
711.5 million tonnes (Anonymous, 2016). The occurrence of grain discoloration has increased in South Gujarat in mid late and late varieties. It is major problem in rice cultivation as it reduces quality and quantity of rice production. It causes loss to producer and agro processors. The infected grain remain unfilled or discolored, become chaffy which are light in weight and during milling become powder or break resulting in poor recovery. Considering the importance of disease, a field experiment with different newer as well as combination of fungicides available in the market was laid out to test their efficacy against grain discoloration disease of rice.

\section{Materials and Methods}

A field experiment was laid out in randomized block design with six fungicides keeping three replications. Fungicides and their concentrations used for spraying to control the grain discoloration of rice are mentioned in Table 1.

Efficacy of each fungicide was compared with control plot, which was sprayed with water only. The gross plot size was $5.4 \times 3.6 \mathrm{~m}^{2}$ and net plot size was $5.1 \times 3.2 \mathrm{~m}^{2}$. with $15 \times 20 \mathrm{~cm}^{2}$. A popular rice variety Jaya was used for the study. Seeds were

\begin{tabular}{llcc}
\hline \multicolumn{3}{l}{ Table 1: Fungicides and their dosage } \\
\hline $\begin{array}{l}\text { Sr. } \\
\text { No }\end{array}$ & Treatments details & $\begin{array}{c}\text { Conc. } \\
(\%)\end{array}$ & $\begin{array}{c}\text { Dosage } \\
\left(\mathrm{l}^{-1}\right)\end{array}$ \\
\hline $\mathrm{T}_{1}$ & Trifloxystrobin 25\% + Tebucon- & 0.03 & $0.4 \mathrm{~g}$ \\
& azole 50\% (75 WG ) & & \\
$\mathrm{T}_{2}$ & Kresoxim methyl 44.3 SC & 0.05 & $1.0 \mathrm{ml}$ \\
$\mathrm{T}_{3}$ & Azoxystrobin 25 SC & 0.025 & $1.0 \mathrm{ml}$ \\
$\mathrm{T}_{4}$ & Tricyclazole 75 WP & 0.05 & $0.6 \mathrm{~g}$ \\
$\mathrm{~T}_{5}$ & Carbendazim 50 WP & 0.025 & $1.0 \mathrm{~g}$ \\
$\mathrm{~T}_{6}$ & Propiconazole 25 EC & 0.025 & $1.0 \mathrm{ml}$ \\
$\mathrm{T}_{7}$ & Check / Control & - & - \\
\hline
\end{tabular}

sown in the month of June and planted in July. Before sowing, healthy seeds were water soaked overnight and incubated in the gunny bags for better sprouting in the nursery. The land was prepared by puddling method. All standard agronomic practices were followed except using higher nitrogenous (150 $\left.\mathrm{kg} \mathrm{ha}^{-1}\right)$ fertilizer dose than the normal dose (N2: $\mathrm{P}_{2} \mathrm{O} 5: \mathrm{K}_{2} \mathrm{O}$ : 100:30:00). The first spray of fungicides on cv. Jaya was carried out at boot leaf stage and the remaining two sprays were carried out after 10 days interval. Ten hills from each treatment were randomly selected and labeled. These labeled plants were observed for disease incidence, discolored, unfilled, healthy grains and the yield of grain and straw per plot was also recorded. 


\section{Results and Discussion}

Effectiveness of fungicides was compared with control, where no fungicide was sprayed. The percentage of healthy grains, discolored grains and unfilled grains were work out and presented in Table 2 and 3.

\subsection{Healthy grains}

The results on effect of fungicides on healthy grains are given in Table 2. The treatment trifloxystrobin 25\% + tebuconazole $50 \%$ found significantly superior which was at par with propiconazole $25 \mathrm{EC}$ and carbendazim 50 WP during $1^{\text {st }}$ year and treatment propiconazole $25 \mathrm{EC}$ during $2^{\text {nd }}$ year. While in $3^{\text {rd }}$ year, the treatment propiconazole 25 EC recorded significantly produced higher healthy grains which was at par with treatment trifloxystrobin $25 \%$ + tebuconazole $50 \%$. In case of pooled results, the treatments trifloxystrobin $25 \%$ + tebuconazole 50\% (75 WG) produced significantly higher healthy grain which was at par with propiconazole (25 EC). The year effect was found non significant.

\subsection{Discolored grains}

The spraying of fungicides significantly reduced the discolored grains than in control. The results on discolored grain are given in Table 2 . The treatment $T_{1}$ found significantly superior which was at par with $T_{6}, T_{5}$ and $T_{4}$ during the $1^{\text {st }}$ year and treatment $\mathrm{T}_{6}$ during $2^{\text {nd }}$ year. While in $3^{\text {rd }}$ year, the treatment $\mathrm{T}_{6}$ recorded significantly reduced the discolored grain which was at par with treatment $\mathrm{T}_{1}$. In case of pooled results, the treatment trifloxystrobin 25\% + tebuconazole 50\% (75 WG) $\left(T_{1}\right)$ significantly reduced the discolored grain which was at par with propiconazole (25 EC) $\left(\mathrm{T}_{6}\right)$ and carbendazim $50 \mathrm{WP}$ $\left(\mathrm{T}_{5}\right)$. The year effect was found non significant.

\subsection{Unfilled grains}

The results on unfilled grain are given in Table 3 . The spraying of fungicides significantly reduced the unfilled grain than in control. Among these fungicidal spray treatments, trifloxystrobin 25\% + tebuconazole 50\% (75 WG) $\left(T_{1}\right)$ and propiconazole $25 \mathrm{EC}\left(\mathrm{T}_{6}\right)$ were at par. Both fungicides were found superior and significantly reduced the unfilled grains than the rest of fungicides. The year effect was found non significant. The present finding is more or less in line with earlier workers viz., Singh and Chand (1985) who reported that zineb, ridomil and carbendazim effectively manage the grain discoloration of rice. Sumangala et al. (2008) revealed that mancozeb at $0.3 \%$ ( $97.37 \%$ inhibition) was significantly superior among the non-systemic fungicides evaluated at three concentrations $(0.1,0.2$ and $0.3 \%)$. Among the systemic fungicides, metalaxyl showed $98.48 \%$ inhibition of mycelial growth at $0.3 \%$ concentration followed by carbendazim (95.25\% inhibition at 0.3\%). Hafiz et al. (2009) found that carbendazim was best followed by Topsin M, Dithane M-45 and Ridomil, respectively. Diseased grains treated with both of these fungicides showed maximum germination and least seedling mortality.

Table 2: Effect of fungicidal sprays on healthy and discolored grain

\begin{tabular}{llcccccccc}
\hline Sr. & Treatments & \multicolumn{4}{c}{ Healthy grain (\%) } & \multicolumn{5}{c}{ Discolored grain (\%) } \\
\cline { 3 - 9 } No & & 2013 & 2014 & 2015 & Pooled & 2013 & 2014 & 2015 & Pooled \\
\hline $\mathrm{T}_{1}$ & Trifloxystrobin 25 + Tebuconazole & 57.79 & 61.30 & 57.72 & 58.94 & 21.16 & 20.36 & 22.86 & 21.46 \\
& 50 (75 WG ) & $(71.50)$ & $(76.75)$ & $(71.25)$ & $(73.17)$ & $(13.25)$ & $(12.25)$ & $(15.25)$ & $(13.58)$ \\
$\mathrm{T}_{2}$ & Kresoxim methyl 44.3 SC & 53.14 & 53.28 & 53.18 & 53.20 & 24.72 & 26.68 & 26.82 & 26.07 \\
& & $(64.00)$ & $(64.25)$ & $(64.00)$ & $(64.08)$ & $(17.50)$ & $(20.25)$ & $(20.50)$ & $(19.42)$ \\
$\mathrm{T}_{3}$ & Azoxystrobin 25 SC & 51.80 & 50.63 & 47.44 & 49.96 & 25.09 & 29.50 & 30.81 & 28.47 \\
& & $(61.75)$ & $(59.75)$ & $(54.25)$ & $(58.58)$ & $(18.00)$ & $(24.25)$ & $(26.25)$ & $(22.83)$ \\
$\mathrm{T}_{4}$ & Tricyclazole 75 WP & 54.81 & 53.45 & 48.18 & 52.15 & 22.96 & 25.82 & 28.74 & 25.84 \\
& & $(66.75)$ & $(64.50)$ & $(55.50)$ & $(62.25)$ & $(15.25)$ & $(19.00)$ & $(23.25)$ & $(19.17)$ \\
$\mathrm{T}_{5}$ & Carbendazim 50 WP & 56.38 & 54.68 & 51.52 & 54.19 & 22.08 & 25.27 & 27.27 & 24.87 \\
& & $(69.25)$ & $(66.50)$ & $(61.25)$ & $(65.67)$ & $(14.25)$ & $(18.25)$ & $(21.00)$ & $(17.83)$ \\
$\mathrm{T}_{6}$ & Propiconazole 25 EC & 57.07 & 59.51 & 58.29 & 58.29 & 21.59 & 22.03 & 22.44 & 22.02 \\
& & $(70.25)$ & $(74.00)$ & $(72.25)$ & $(72.17)$ & $(13.75)$ & $(14.25)$ & $(14.75)$ & $(14.25)$ \\
$\mathrm{T}_{7}$ & Check / Con-trol & 43.71 & 45.58 & 39.46 & 42.92 & 29.16 & 32.26 & 36.56 & 32.66 \\
& & $(47.75)$ & $(51.00)$ & $(40.50)$ & $(46.42)$ & $(23.75)$ & $(28.50)$ & $(35.50)$ & $(29.25)$ \\
& SEm \pm & 1.37 & 1.41 & 1.89 & 1.57 & 1.07 & 1.04 & 1.29 & 1.14 \\
& CD (p=0.05) & 4.07 & 4.17 & 5.59 & 4.46 & 3.18 & 3.07 & 3.82 & 3.23 \\
& C.V. \% & 6.14 & 6.21 & 7.42 & 6.96 & 9.02 & 7.97 & 9.24 & 8.79 \\
& YxT & & & & N.S & & & & N.S \\
\hline
\end{tabular}

Figures in the parenthesis are original value whereas outside the parenthesis is Arc sine transform value 


\begin{tabular}{llcccc}
\hline \multicolumn{5}{l}{ Table 3: Effect of fungicidal sprays on unfilled grain } \\
\hline $\begin{array}{l}\text { Sr. } \\
\text { No }\end{array}$ & Treatments & \multicolumn{5}{c}{ Unfilled grain (\%) } \\
\cline { 3 - 6 } & & 2013 & 2014 & 2015 & Pooled \\
\hline $\mathrm{T}_{1}$ & Trifloxystrobin 25 + Tebucon-azole 50 (75 WG ) & $22.77(15.25)$ & $19.22(11.00)$ & $21.30(13.50)$ & $21.10(13.25)$ \\
$\mathrm{T}_{2}$ & Kresoxim methyl 44.3 SC & $25.42(18.50)$ & $23.09(15.50)$ & $22.99(15.50)$ & $23.83(16.50)$ \\
$\mathrm{T}_{3}$ & Azoxystrobin 25 SC & $26.71(20.25)$ & $23.53(16.00)$ & $26.19(19.50)$ & $25.47(18.58)$ \\
$\mathrm{T}_{4}$ & Tricyclazole 75 WP & $25.07(18.00)$ & $23.94(16.50)$ & $27.36(21.25)$ & $25.46(18.58)$ \\
$\mathrm{T}_{5}$ & Carbendazim 50 WP & $23.82(16.50)$ & $22.86(15.25)$ & $24.84(17.75)$ & $23.84(16.50)$ \\
$\mathrm{T}_{6}$ & Propiconazole 25 EC & $23.47(16.00)$ & $19.73(11.75)$ & $21.01(13.00)$ & $21.41(13.58)$ \\
$\mathrm{T}_{7}$ & Check / Con-trol & $32.26(28.50)$ & $28.33(23.00)$ & $29.10(24.00)$ & $29.90(25.17)$ \\
& SEm \pm & 1.36 & 1.75 & 1.79 & 1.64 \\
& CD ( $p=0.05)$ & 4.03 & 5.18 & 5.29 & 4.66 \\
& C.V. \% & 10.60 & 15.24 & 14.48 & 13.45 \\
& Y×T & & N.S & & \\
\hline
\end{tabular}

Figures in the parenthesis are original value whereas outside the parenthesis is Arc sine transform value

\subsection{Grain and straw yield}

The results on grain and straw yield of paddy affected by different treatments are given in Table 4 . The results indicated that effect of different treatments was significant during all the individual years as well in pooled results. All the treatments were found significantly superior over control for grain and straw yield of paddy. During $1^{\text {st }}$ and $2^{\text {nd }}$ year, the treatment $\mathrm{T}_{1}$ recorded significantly higher grain and straw yield which was at par with $\mathrm{T}_{6}$. While in $3^{\text {rd }}$ year, the treatment $\mathrm{T}_{6}$ recorded significantly higher grain and straw yield which was at par with treatment $T_{1}$. In case of pooled results, the treatments $\mathrm{T}_{6}$ (propiconazole $25 \mathrm{EC}$ ) @ $1.0 \mathrm{ml} \mathrm{l}^{-1}$ ) recorded significantly higher grain yield $\left(5353 \mathrm{~kg} \mathrm{ha}^{-1}\right)$ and straw yield $\left(7011 \mathrm{~kg} \mathrm{ha}^{-1}\right)$ which was at par with $\mathrm{T}_{1}$ (trifloxystrobin $25 \%+$ tebuconazole 50\%)@ $0.4 \mathrm{~g} \mathrm{l}^{-1}$ ) i.e. $5341 \mathrm{~kg} \mathrm{ha}^{-1}$ grain and $7001 \mathrm{~kg} \mathrm{ha}^{-1}$ straw yield.

\begin{tabular}{|c|c|c|c|c|c|c|c|c|c|}
\hline \multirow{2}{*}{$\begin{array}{l}\text { Sr. } \\
\text { No }\end{array}$} & \multirow[t]{2}{*}{ Treatments } & \multicolumn{4}{|c|}{ Grain Yield $\left(\mathrm{kg} \mathrm{ha}^{-1}\right)$} & \multicolumn{4}{|c|}{ Straw Yield $\left(\mathrm{kg} \mathrm{ha}^{-1}\right)$} \\
\hline & & 2013 & 2014 & 2015 & Pooled & 2013 & 2014 & 2015 & Pooled \\
\hline $\mathrm{T}_{1}$ & Trifloxystrobin 25 + Tebucon-azole 50 ( 75 WG ) & 4893 & 5723 & 5407 & 5341 & 6633 & 7322 & 7047 & 7001 \\
\hline$T_{2}$ & Kresoxim methyl $44.3 \mathrm{SC}$ & 4370 & 4392 & 4979 & 4580 & 6296 & 5830 & 6419 & 6182 \\
\hline $\mathrm{T}_{3}$ & Azoxystrobin $25 \mathrm{SC}$ & 4320 & 3928 & 3960 & 4069 & 6204 & 6196 & 5913 & 6104 \\
\hline $\mathrm{T}_{4}$ & Tricyclazole 75 WP & 4384 & 4852 & 4749 & 4662 & 6320 & 6748 & 6143 & 6404 \\
\hline $\mathrm{T}_{5}$ & Carbendazim 50 WP & 4401 & 4888 & 4902 & 4730 & 6365 & 6872 & 6281 & 6506 \\
\hline $\mathrm{T}_{6}$ & Propiconazole 25 EC & 4873 & 5418 & 5767 & 5353 & 6510 & 7215 & 7307 & 7011 \\
\hline \multirow[t]{5}{*}{$\mathrm{T}_{7}$} & Check / Con-trol & 3428 & 3442 & 3462 & 3444 & 4994 & 5492 & 5744 & 5410 \\
\hline & SEm \pm & 149 & 225 & 203 & 195 & 183 & 202 & 290 & 230 \\
\hline & $\mathrm{CD}(p=0.05)$ & 444 & 670 & 605 & 554 & 543 & 601 & 862 & 652 \\
\hline & C.V. $\%$ & 6.84 & 9.69 & 8.59 & 8.52 & 5.91 & 6.20 & 9.06 & 7.24 \\
\hline & $Y \times T$ & - & - & - & NS & - & - & - & NS \\
\hline
\end{tabular}

\section{Conclusion}

Among the six fungicides screened against rice grain discoloration disease, trifloxystrobin $25 \%$ + tebuconazole $50 \%$ @ $0.4 \mathrm{~g} \mathrm{I}^{-1}$ and propiconazole $25 \mathrm{EC} @ 1.0 \mathrm{ml} \mathrm{l}^{-1}$ was found most effective against rice grain discoloration.

\section{Acknowledgement}

The authors express their gratitude to The Director of Research, Dean P.G. Studies, Navsari Agricultural University, Navsari, Gujarat for providing necessary facilities during the present investigations. Authors are also thankful to Indian 
Institute of Rice Research, Department of Plant Pathology, Hyderabad.

\section{References}

Anonymous, 2016. Fourth advance estimates of production of food grains for 2015-16, Department of Agriculture and Cooperation, Gujarat state, Gandhinagar, 102.

Hafiz Muhammad Imran Arshad, Junaid Ahmad Khan, Sumaira Naz, Salik Nawaz Khan, Muhammad Akram, 2009. Grain discoloration disease complex: a new threat for rice crop and its management. Pakistan Journal of Phytopathology 21, 31-36.

Singh, R., Chand, H., 1985. Rice grain discoloration and its chemical control. International Rice Research Notes $10,16$.

Sumangala, K., Patil, M.B., Nargund, V.B., Ramegowda, G., 2008. Evaluation of fungicides, botanicals and bioagents against Curvularia lunata, a causal agent of gain discoloration in rice. Journal of Plant Disease Sciences 3, 159-164. 